\title{
When misconduct in public office is really a sexual offence
}

\section{Catarina Sjölin and Helen Edwards ${ }^{1}$}

\section{Introduction}

The common law offence of misconduct in public office (MiPO) had fallen into disuse before its slow resurrection in the mid-twentieth century, ${ }^{2}$ yet it is now an offence which appears before the courts often enough for the Law Commission to consult about what to do with it. The Law Commission's consultation is hardly surprising because, in common with many surviving but non-mainstream common law offences ${ }^{3}$, the elements of the offence are so amorphous as to be uncertain ${ }^{4}$, or commendably flexible ${ }^{5}$ (depending on your point of view). It is fair to say that the English and Wales consensus is for the former view. The offence exists in many common law jurisdictions, although it is not held in such disdain in all of them. ${ }^{6}$

The elements of the offence have settled in recent times as:

(1) a public officer acting as such;

(2) wilfully neglects to perform his duty and/or wilfully misconducts himself;

(3) to such a degree as to amount to an abuse of the public's trust in the office holder;

\footnotetext{
${ }^{1}$ Both Senior Lecturers at Nottingham Law School, Nottingham Trent University.

${ }^{2}$ See $R v$ Hudson [1956] 2 QB 252, CCA, R v Llewellyn-Jones and Lougher (1966) 51 Cr App R 4, Cardiff Assizes (Widgery J) and $R v$ Dytham (1979) $69 \mathrm{Cr}$ App R 387, CA. The offence received its clearest explanation before modern times in $R v$ Bembridge (1783) 3 Doug 327; 99 ER 679 in which Lord Mansfield stated that the underlying principles are old and relies upon an anonymous case reported at B. B. H. 2 Ann. 6 Mod. 96.

${ }^{3}$ For example, conspiracy to corrupt public morals, conspiracy to defraud and outraging public decency.

${ }^{4}$ See helpful summary at Law Commission Reforming Misconduct in Public Office, A Consultation Paper (2016, London: The Stationery Office) (Law Com 229) at 2.18 and also, for example, S. Parsons Misconduct in Public Office - Should it Still be Prosecuted? (2012) 76 J Crim L 179.

${ }^{5}$ Mark Knights in Law Commission Reforming Misconduct in Public Office, A Consultation Paper (2016, London: The Stationery Office) (Law Com 229) at 2.122.

${ }^{6}$ The offence is enjoying a particular vogue in Australia - see D Lusty Revival of the Common Law Offence of Misconduct in Public Office (2014) 38 Crim LJ 337.
} 
(4) without reasonable excuse or justification. ${ }^{7}$

One of the problems identified by the Commission in its first paper outlining the issues is that "the fault element that must be proved for the offence differs depending on the circumstances. That is an unusual and unprincipled position." 8 An offence more commonly dealt with by practitioners than opined upon by academics, it is not mentioned in Smith \& Hogan but is dealt with at some length by Archbold ${ }^{9}$ where the fault element is considered and defined as something non-accidental and requiring awareness or subjective recklessness as to whether the duty arose at all, as well as to the conduct of the defendant if it did:

"as to the consequences, these are not an ingredient of the offence as such but the consequences as to which the defendant was reckless will need to be considered for ... deciding whether the conduct in question falls so far below the standard of conduct to be expected as to amount to the offence ... the consequences, viewed subjectively ... will often influence the decision as to whether the conduct amounted to an abuse of the public's trust in the office holder."

The threshold is a high one and even a serious mistake will not be sufficient for misconduct.

It is unarguable that the offence covers a very wide range of conduct ranging from a councillor influencing a council officer to move the route of a planned

\footnotetext{
${ }^{7}$ Attorney General's Reference (No. 3 of 2003) [2004] 2 Cr App R 23, CA. Other common law jurisdictions have settled upon very similar formulations, for example: $R v$ Boulanger [2006] 2 SCR 49 (Canada, where the offence was codified), $R v$ Quach [2010] VSCA 106, $R v$ Obeid [2016] NSWSC 974 (Australia) and Shum Kwok Sher v HKSAR [2002] 2 HKLRD 793 (Hong Kong).

${ }^{8}$ Law Commission Misconduct in Public Office Issues Paper 1: The Current Law (2016: The Law Commission, London) at 1.11(4).

${ }^{9}$ J. Richardson et al, Archbold Criminal Pleading, Evidence and Practice 2016 at 25-403.
} 
$\operatorname{road}^{10}$ to a police officer using his job in order to sexually exploit vulnerable women. ${ }^{11}$ The flexibility of common law offences, which enables them to adapt to changing practical situations, can result in a lack of clarity and blurred boundaries. A particular problem in $\mathrm{MiPO}$ is that the type of conduct it covers is so incredibly varied. Although abuse of power is at the heart of the offence, the councillor's abuse of his position is rather different to that of the police officer and their conduct is even more different.

\section{Sexual misconduct as MiPO}

There are some, but not many, reported appeal cases involving MiPO, so, to get a clearer view of what kind of activity is being charged as MiPO, or is resulting in convictions for $\mathrm{MiPO}$, we also examined newspaper reports going back fourteen years to 2002 looking for sexual misconduct which was also alleged to be misconduct in public office. Our analysis of newspaper reports meant that it was sometimes possible to trace cases through from first appearance to trial and see how charges changed over time, something often not possible from appeal case reports. We were also able to capture cases where there were acquittals or where the defendant was convicted but did not appeal.

\section{The cases}

Cases involving 19 defendants were reported in the law reports. Three of these were augmented by details from newspaper reports and 42 defendants/suspects were mentioned in newspapers alone. Categorising cases by defendant, 36 were police officers and police employees, 15 worked in or with prisons (including as nurses), four were probation workers and one was a court clerk. There was one Church of England cleric ${ }^{12}$ and two council

\footnotetext{
${ }^{10} R v$ Speechley [2004] EWCA Crim 3067, [2005] 2 Cr App R (S) 15.

${ }^{11} R v$ Kenny Lewis [2010] 2 Cr App R (S) 104.

${ }^{12}$ Right Reverend Peter Ball (R v Peter Ball (2015) Central Criminal Court (unreported))
} 
CCTV operators ${ }^{13}$ charged with MiPO, but National Health Service medical professionals were held not to be public office holders ${ }^{14}$ and MPs who may have sexual misconducted themselves not charged. ${ }^{15}$

It is startling how those working in the criminal justice system (CJS) were the overwhelming majority of perpetrators of sexual misconduct related to their office. As we relied on a lot of newspaper reports, this may be because such defendants are more newsworthy. That does not seem particularly likely as it is the sexual element of the misconduct which engages the salacious interest of reporters (and their readers) at least as much as the office holder's position. If a council officer had been demanding sexual favours to write off Council Tax bills, it seems very unlikely that there would not be significant local reporting at least (and our researches took in local as well as national press); the voyeuristic CCTV operators' case was reported in the press.

There is also the possibility that public office holders outside the CJS are misconducting themselves sexually, but there is no complaint to the police or the Crown Prosecution Service does not recommend charge. Neither possibility seems likely. There is doubtless underreporting of this form of sexual misconduct as there is of all sexual misconduct, 16 but no reason for sexual misconduct by other public office holders being particularly underreported. It would be harder psychologically and practically for a victim to report to the police misconduct by police officers than by, for example,

\footnotetext{
${ }^{13}$ Kevin Judge and David Welsh (Brian Roberts CCTV Staff Voyeurs The Mirror, 7 December 2005).

${ }_{15}$ Nigel Griffiths (MP (The Scotsman, Police rule our criminal inquiry into MP's sex encounter in Commons 4 April 2009 (available online at http://www.scotsman.com/news/politics/policerule-out-criminal-inquiry-into-mp-s-sex-encounter-in-commons-1-1351533) accessed 20 December 2016) and John Prescott MP (Marie Woolf and Sophie Goodchild Prescott's office sex romps 'broke the law' The Independent on Sunday, 7 May 2006).

${ }^{16}$ Ministry of Justice, Home Office, Office for National Statistics An Overview of Sexual Offending in England and Wales, Statistics Bulletin, 10 January 2013, Executive Summary and pp16-18.
} 
civil servants. It does not seem likely that there is underreporting of sexual misconduct by non-CJS public office holders specifically.

Our suggestion is that the power which those in the CJS have, particularly police and prison workers, is particularly great and this is the reason for the greater prevalence of sexual misconduct by CJS workers than by other public office holders. Misconduct may be more obviously wrong because of the power imbalance. The temptation is greater for office holders to predate, should they be so inclined, but also for them to be predated upon to corrupt that powerful system in favour of the sexual partner. Although there are others in our society who hold great power over the public - in particular medical professionals - they are not considered to be holders of public office and so not caught by the offence.

\section{Types of sexual misconduct covered}

It became clear that the sexual misconduct in these cases fell into three main categories: 17

(1) The defendant abused his/her position for sexual gratification (often, but not always, sexual relations), usually with a vulnerable person - an exploitation of the public office for sexual gain.

(2) The defendant did not exploit the public office, but instead engaged in a relationship, which by its very nature corrupted the system, and left the defendant open to being further corrupted. Such a relationship will usually be sexual, but need not be. ${ }^{18}$

\footnotetext{
${ }^{17}$ As identified in Catarina Sjölin and Helen Edwards Law Commission Consultation Misconduct in Public Office, 21 March 2016 (submitted to Law Commission and referred to in the second consultation document but unpublished). One case fell outside these categories as it involved a police officer working as a prostitute: $R v$ Victoria Thorne (2009) Newcastle upon Tyne Crown Court (unreported) (Sophie Doughty PC Call Girl's Seedy Past Newcastle Evening Chronicle, 5 August 2009).

${ }^{18} R v$ Waddington [2015] EWCA Crim 367, CA where the relationship was described as emotional but not sexual.
} 
(3) The defendant did not exploit his/her position or corrupt the system, but had sex whilst on public duty. (A number of cases involved the defence contention that there was a consensual relationship and the only issue was that the officer was on duty, but in the majority of these the prosecution allegation was that the officer was predating his/her victim. There were, however, some cases were it was common ground that there was no exploitation and the wrong was simply sex on duty.)

\section{Interrelation with sexual offences}

It emerged from our analysis that there was not a consistent approach to the charging of MiPO for sexual misconduct. Sometimes no sexual offence was charged at all19, sometimes MiPO was a lesser alternative to a non-consensual sexual offence ${ }^{20}$ and sometimes no offence was charged and disciplinary proceedings were mounted instead. ${ }^{21}$ There is now Crown Prosecution Service legal guidance in relation to $\mathrm{MiPO}$ which states that statutory offences should be charged in preference to MiPO, with the MiPO aspect being relied upon as an aggravating feature for sentence, unless (a) there is no statutory offence, (b) the real wrong is the breach of public duty or (c) the court's sentencing powers would otherwise be inadequate. ${ }^{22}$ In sexual cases the nonconsent offences in the Sexual Offences Act $2003^{23}$ (SOA 2003) are the obvious statutory offences which carry sufficiently high maximum sentences that MiPO is not needed to ensure that the court has sufficient sentencing powers. MiPO is being used, however, as an alternative charge in many cases and, in

\footnotetext{
${ }^{19}$ For example, $R v$ Fletcher [2012] 1 Cr App R (S) 62, CA, R v Gary Hansford (2007) Leeds Crown Court.

${ }^{20}$ For example, $R v$ Geoffrey Middlehurst (1999), Hull Crown Court, $R v$ Kenny Lewis [2010] 2 Cr App R (S) 104, CA and Exeter Crown Court.

${ }^{21}$ See bad character evidence of disciplinary proceedings relied upon in $R v$ Stephen Mitchell (2011) Newcastle Crown Court.

${ }^{22}$ Crown Prosecution Service, Legal Guidance: Misconduct in Public Office available online at http://www.cps.gov.uk/legal/1_to_o/misconduct_in_public_office/ (accessed 21 December 2016). ${ }^{23}$ Sexual Offences Act 2003 ss. 1-4.
} 
the absence of clear advice as to how MiPO be used as an alternative, an inconsistent approach is being taken.

We noted that MiPO has been regularly used as a pragmatic way for sexual offending to be dealt with, where the defendant pleaded guilty to MiPO having been charged initially with apparently appropriate sexual offences. ${ }^{24}$ Such a guilty plea may be an attractive option to the defendant because it is not a conviction for a sexual offence (the consequences of a conviction for which are greater than for MiPO). It may be an attractive option to the prosecution when the sexual offence alternatives are non-consensual and the victim may be a poor or reluctant witness. Although it is understandable that pragmatic decisions have sometimes been taken, that does not mean that it is appropriate. MiPO is effectively providing a non-sexual, less serious alternative offence in cases where the defendant is in public office which is not available to a defendant who is not in public office, resulting in the paradoxical situation that defendants whose offending is aggravated by their public office end up with convictions for a lesser offence.

The limits of $\mathrm{MiPO}$

The limitation of MiPO to those holding public office is understandable from historical and theoretical perspectives, but it leads to what look like inconsistencies, or even injustices, from the lay perspective. Nurses working within a prison are holders of public office ${ }^{25}$ as is a Church of England priest, ${ }^{26}$ but a paramedic employed by a National Health Service Trust is not. ${ }^{27}$

\section{Analysis}

The wrongs at the heart of the MiPO cases

\footnotetext{
${ }^{24}$ For example, $R v$ Fletcher [2012] 1 Cr App R (S) 62, CA, R v Peter Jee (2011 - 2013)

Manchester Minshull Crown Court and $R v$ Leigh Brightman (2015) Central Criminal Court.

${ }^{25} \mathrm{R} v$ Cosfrod, Falloon and Flynn [2013] 2 Cr App R 8, CA.

${ }^{26} R v$ Peter Ball (2015) Central Criminal Court (unreported).

${ }^{27} \mathrm{R} v$ William Mitchell [2014] 2 Cr App R 2, CA,
} 
It is important to analyse what the wrong is at the heart of the three categories of conduct identified. Despite them all involving sexual activity, it is submitted the wrong is different in each one.

In the first category the wrong is two-fold. The defendant has abused his/her position of authority, which in itself involves an abuse of the public's trust because it is the public which has granted that authority to the defendant. Beyond that, there is a specific sexual wrong against a specific person. This does not necessarily mean that there is a violation of the person's autonomy as that suggests that consent is all that matters; autonomy is very important but protection of autonomy is not the only aim of the laws on sexual offending. The wrong can be transgressing a societal line rather a line set by the person exercising their autonomy. For instance, incestuous sexual intercourse may be factually consensual, but is still a criminal wrong ${ }^{28}$, as is consensual sexual contact between a teacher and 17 year old pupil ${ }^{29}$ or a carer and mentally disordered patient ${ }^{30}$.

In the second category the sexual nature of the misconduct is really background, the wrong is the corruption of the system for those in it and the public. For example, the prison officer who engages in a relationship with a prisoner is corrupting the system not just by giving favours to the prisoner (or being blackmailed into doing so) but also by treating other prisoners differently. The public, it goes without saying, are also wronged having entrusted the prisoner to the officer's care.

The final category is not always going to involve a criminal wrong at all. The conduct may amount to a breach of the office holder's employment terms or code of conduct and be dealt with under these instead. Thus the married MP

\footnotetext{
28 SOA 2003 ss. 64 and 65.

29 SOA 2003 ss. 16-19.

30 SOA 2003 ss. 38-41.
} 
who had sex with his mistress at the Houses of Parliament ${ }^{31}$ and the Chief Constable who missed meetings to have sex with his mistress ${ }^{32}$ were disciplined but not prosecuted. When a police office was convicted for what the jury must have found was not unconsensual sex whilst on duty, a retrial was not allowed when the conviction was quashed on the ground of fresh evidence, Elias LJ questioning whether the conduct could amount to MiPO. ${ }^{33}$ The answer to this query must be that it depends on the circumstances. A police officer, who has sexual intercourse with her partner because they are trying to get pregnant and she is particularly fertile at that time, is not causing any wrong to anyone. In contrast, there could be a criminal wrong if the officer neglected an aspect of her duty whilst having, or in order to have, the sexual relations, for example, failing to answer an urgent call for assistance over the police radio. This wilful neglect would be a dereliction of duty, as the officer's failure to intervene in Dytham was, the sexual activity merely being what it was that the defendant was doing instead of her duty.

As the three categories have the overlapping wrong of abuse of the trust placed in the defendant by the public, one can see why MiPO unites them, but the other wrongs mean, we submit, that to leave them all covered by MiPO is not appropriate.

Clarity and certainty are usually held up as requirements of the rule of law, 34 particularly criminal law because breach of it has such grave consequences for

\footnotetext{
${ }^{31}$ Nigel Griffiths MP (The Scotsman, Police rule our criminal inquiry into MP's sex encounter in Commons, 4 April 2009 (available online at http://www.scotsman.com/news/politics/police-rule-out-criminal-inquiry-into-mp-s-sexencounter-in-commons-1-1351533) accessed 20 December 2016).

32 Terry Grange (Press Association Newswire, Chief Constable 'Abused Position' says Watchdog, 6 May 2008).

${ }^{33} R v$ Stone [2012] EWCA Crim 2911, CA at [37].

${ }^{34}$ See for instance A.V. Dicey, Introduction to the Study of the Law of the Constitution $8^{\text {th }}$ edn (London: Macmillan, 1915), Lon Fuller, The Morality of Law $2^{\text {nd }}$ revised edn (New Haven; Yale University Press, 1969), Joseph Raz "The Rule of Law and its Virtue" in The Authority of Law: Essays on Law and Morality (Oxford: Clarendon Press, 1979), H.L.A. Hart The Concept of Law, $2^{\text {nd }}$ edn (Oxford: Clarendon Press, 1994) and Tom Bingham in The Rule of Law (London: Allen Lane, 2010).
} 
the defendant. The citizen must be able to know what s/he should not do. Further, once the defendant is convicted of an offence, it should be clear what s/he has done: his/her offending must be properly labelled both to identify what $\mathrm{s} /$ he has done and what was criminally wrong about it. 35 The flexibility inherent in the broad terms giving the elements of MiPO mean that it is too wide to precisely and accurately communicate to people what a conviction for it means the defendant has actually done. Obviously, labelling will always involve some lack of detail, otherwise each and every piece of criminal conduct would need its own label, but there has to be some clarity about what type of conduct has occurred. Where a label hides the nature of conduct rather than explaining it, it is submitted that it fails as a criminal label.

Currently all three strands of sexual misconduct could lead to conviction for the same offence and this offence does not adequately or appropriately reflect what has happened. It marks the defendant out as one who has failed in some respect to fulfil his/her duty, but ignores all other aspects of the nature of the breach and the effect that it had or risked.

This failure in labelling is a particular problem when MIPO is used for sexual offending. With the vast majority of sexual offences now to be found in one Act, it is frankly misleading to cover some sexual misconduct with an offence that does not even give a hint of sexual offending.

The labelling of the conduct as a breach of public duty gets in the way of recognising the category one sexual wrong (exploitation of position for sexual gain) by a person in a position of authority against a vulnerable person. If the wrong in category one conduct is not, at heart, the breach of public duty, then it is harder to justify distinguishing the priest from the paramedic when both have used their position to prey upon the vulnerable.

35 J Chalmers and F Leverick, Fair Labelling in Criminal Law (2008) Modern Law Review 217. 
Where the misconduct was sexual, one unifying theme emerged which was that there was no problem with identifying the fault element required. This suggests that the criticism based on the changing fault element ${ }^{36}$ is at heart a criticism based on the sheer range of conduct covered by MiPO. This fortifies our view that, at least with regard to offences involving sexual conduct, the conduct and the wrong which it creates/risks should determine the offence, rather than the public office of the defendant being the determinative factor in the offence.

Inconsistency as to who may be a defendant

The Court of Appeal in $2004^{37}$ referred to the unfairness that could arise where people who carry out similar duties may or may not be liable to prosecution depending on whether they can be defined as 'public officers'.

“What were once purely public functions are now frequently carried out by employees in private employment, for example those concerned with security at courts and the transport of defendants."

The Court declined to define a public officer, however, but said:

'This potential unfairness adds weight, in our view, to the conclusion that the offence should be strictly confined but we do not propose to develop the point or to consider further the question of what, for present purposes, constitutes a public office.'

It is hardly surprising that the Court of Appeal did not wish to widen MiPO to suddenly - and retrospectively - encompass many new people as potential defendants, but the inconsistency in MiPO is heightened by this decision.

\footnotetext{
${ }^{36}$ See, for instance, Law Commission Misconduct in Public Office Issues Paper 1: The Current Law (2016: The Law Commission, London) at 4.3 (4).

37 Attorney General's Reference (No 3 of 2003) [2004] EWCA Crim 868, [2005] Q.B. 73 at 91.
} 
Whilst MiPO remains limited to public office holders, there is no labelling problem in this respect, but there is a problem of legitimacy when the reason for what now looks like an artificial divide between, for example, paramedics and nurses working in private prisons can only be justified by reference to the historical development of the offence. The offence should reflect modern society and currently it fails to do so.

The effect on sentencing of using MiPO instead of a sexual offence

Defendants convicted of MiPO for sexual misconduct escape the sentencing regime provided by the SOA 2003. Notification - the requirement to provide details for inclusion on the sex offenders register - automatically follows conviction for a sexual offence, but as MiPO is not a sexual offence, notification does not follow conviction for MiPO. Sexual Harm Prevention Orders ${ }^{38}$ or Sexual Risk Orders ${ }^{39}$ are not available for defendants convicted under MiPO. The Sentencing Council's guideline on sexual offences does not apply to MiPO convictions. The bare police national computer record of the defendant's conviction will record the name of the offence but may not record the details, so the sexual aspect of the offending would not necessarily be apparent if the defendant were to be suspected of further matters, and a bad character application ${ }^{40}$ could be difficult to mount for the same reason.

This is not a difficulty for categories two (the defendant engages in a compromising relationship) and three (the defendant has sex whilst on duty) where the misconduct need not be sexual to be a wrong, but it is a fundamental problem where $\mathrm{D}$ has abused his/her position for sexual gain.

\section{Suggestions for reform}

The breadth of MiPO means the labelling, legitimacy and sentencing problems are unavoidable if the offence is left as it is. The difficulty with the

\footnotetext{
38 Under the SOA 2003 (as amended) ss.103A-K and 122A-K.

${ }^{39}$ Under the SOA 2003 (as amended) s.122A.

40 Under Criminal Justice Act 2003 Part 11, Chapter 1, most likely in relation to propensity.
} 
changeable fault element is also unavoidable if a single offence is retained to cover all the possible conduct currently caught by MiPO. It is submitted that although a general, redrafted MiPO offence would be capable of adequately covering the second and third categories identified above sufficiently, it could not also cover the first category, as it could not properly reflect the sexual wrong at the heart of that category. A sexual offence would reflect the wrong and enable a clearer fault element to be identified - one appropriate to this subset of misconduct in public office. It would cover the situation where there may arguably be consent to the sexual conduct, but that consent was obtained by exploitation of the defendant's position of power. We believe that this is the kind of conduct which is often currently being charged as a non-consent sexual offence but resulting in guilty pleas/convictions for MiPO.

In our response to the first Law Commission consultation on MiPO we identified the problem of the different kinds of sexual misconduct covered and suggested a separate offence and raised the possibility of basing it on the victim's vulnerability. ${ }^{41}$ There are difficulties with this approach. ${ }^{42}$ Sometimes a victim will be inherently vulnerable (with, for example, mental health issues or drug problems) and sometimes the vulnerability will be due to the relationship with the defendant office holder (where, for example, the defendant has arrested the victim). We considered various possible categories and definitions of vulnerability before concluding that focusing on the victim's vulnerability means losing sight of the defendant's misconduct. Better, we have concluded, to focus on the defendant's abuse of his/her position and power whilst adding the necessary sexual element lacking in MiPO. The Commission has suggested that a new sexual offence is outside its

\footnotetext{
${ }^{41}$ See Catarina Sjölin and Helen Edwards Law Commission Consultation - Misconduct in Public Office, 21 March 2016 and Law Commission Reforming Misconduct in Public Office, A Consultation Paper (2016, London: The Stationery Office) (Law Com 229) at Chapter 8; 8.1 8.14 .

42 See Law Commission Reforming Misconduct in Public Office, A Consultation Paper (2016, London: The Stationery Office) (Law Com 229) at 5.66-5.71.
} 
remit ${ }^{43}$ but we respectfully disagree as to suggest reform of MiPO without providing a workable sexual offence to cover the sexual offending which is so often the basis of the MiPO offence would be to leave the Commission's work half done. There is no need for wholesale review of sexual offences to suggest a new sexual offence to replace this aspect of $\mathrm{MiPO}$ as it would be a variant of MiPO based on SOA 2003 foundations.

In searching for a replacement for MiPO for the first category we suggest that the offences that deal with sexual wrongs that are not based on lack of consent should be the starting point:

(1) The child sex offences (where consent is no part of the offence). ${ }^{44}$

(2) The position of trust offences against young people aged under 18.45

(3) The offences committed by carers for the mentally disordered by virtue of their position as carer. 46

(4) Offences involving agreement by a mentally disordered person to sexual relations, that agreement being obtained by threats, deception or inducement. 47

(4) Incest involving only adults. ${ }^{48}$

These offences do not respect the victim's autonomy as the victim's views are irrelevant to the offence (although they may have an effect on the charging decision). The offences instead mark other wrongs, violation of other sexual norms, such as the bars on sexual activity with children and or within prohibited familial degrees. The offences also go some way to protect the vulnerable which can be because of the victim's own vulnerability (where the

\footnotetext{
${ }^{43}$ Law Commission Reforming Misconduct in Public Office, A Consultation Paper (2016, London: The Stationery Office) (Law Com 229) Chapter 8.

44 SOA 2003 ss. 5-8.

45 SOA 2003 ss. 16-19.

46 SOA 2003 ss. 38-41.

47 SOA 2003 ss. 34-37.

48 SOA 2003 ss. 64 and 65.
} 
victim is young ${ }^{49}$, or has a mental disorder ${ }^{50}$ ), but it can be because the defendant is in an ascertainable position of power in relation to the victim (carers of the mentally disordered ${ }^{51}$ and teachers in relation to their older pupils $^{52}$ ). It is therefore possible to draft offences which focus on the defendant's position and abuse thereof for sexual gain rather than the victim's vulnerability and we suggest this as a more appropriate model for the MiPO offence which needs to cover category one activity (abuse of position for sexual gain).

The essential elements we suggest for a MiPO-based sexual offence are:

(1) the defendant holds a position of power over or in relation to the victim

(2) the defendant knows or could reasonably be expected to know of that position of power

(3) the defendant abuses that power and is aware that his/her conduct would be seen by reasonable people as an abuse of that power (4) in order to gain a sexual advantage, namely

(a) sexual contact with the victim, or

(b) making non-physical contact with the victim for the defendant's sexual gratification, or (c) sexual behaviour by the victim, whether alone or with another, for the defendant's sexual gratification.

We recognise the breadth of the elements, particularly the "position of power" and the "abuses that power" elements, but we consider that these are justified. One of the flaws in the SOA 2003 is the over-particularisation of offences, particularly seen in ss.21 and 22, which define in painstaking,

\footnotetext{
49 SOA 2003 ss. 5-12 and 16-19

50 SOA 2003 ss. 30-41.

51 SOA 2003 ss. 38-41.

52 SOA 2003 ss. 16-19.
} 
jargon-based detail who holds a position of trust in relation to a child. As soon as the childcare or protection regime changes its structure or even its terminology, these sections have to be amended. That is not clarity; it is obfuscation by weight of detail. It is important that "position of power" is not too broad to avoid every slight power-imbalance in a sexual relationship to result in a criminal offence, so we suggest that "position of power" be defined as

"holding a position in which the defendant can exert power over the victim's liberty and/or health and/or the investigation/charge/prosecution of a criminal offence which involves the victim and/or someone for whom the victim feels responsible."

This limits the offence to those with real and meaningful power over or in relation to the victim without the need to look at whether the power is "public" or not which, we submit, is irrelevant in relation to this offence. The offence will, we submit, have greater legitimacy borne out of not just clarity but the removal of the artificial distinction between potential defendants based on public office rather than power held. The test enables the offence to respond to political changes to the provision of services without requiring changes to legislation (for example, should there be 'outsourcing' of police powers, the test would still cover privatised officers as the focus is on the power rather than the office).

We rely on the phrase "abuses that power" to avoid criminalising those who might seek to impress a potential partner with their position. Hoping that a potential partner is going to be impressed with the declaration ' $I$ ' $m$ a police officer' involves no criminal wrong that we can identify and where there is no abuse, there is no offence. It will require juries to determine whether the defendant has actually abused his/her position, but this issue is exactly the kind of thing which juries should be left to determine, within constraints. 
Such constraint would be provided both by the requirement that it be abuse rather than use of the power and by a requirement that the judge not leave the offence to go before the jury unless $\mathrm{s} /$ he is satisfied that the abuse can be identified and there is evidence capable of supporting a finding that it does indeed amount to an abuse of power. It is submitted that this would provide sufficient clarity to enable a potential defendant to avoid abusing his/her position and thus being prosecuted. We have consciously echoed the Ghosh approach to dishonesty as, despite the academic unhappiness with it, 53 it is a practical test which is easily applied by juries on a daily basis.

We considered adding the requirement that the abuse be "serious" but concluded that that risks the circularity already seen in the gross negligence manslaughter requirement that the negligence be serious enough to be considered a crime ${ }^{54}$ which is certainly not easily explained theoretically or practically. There is also the risk that a defendant will use a severity requirement to dismiss an allegation as 'banter' or horseplay. Despite the risks, we consider that severity is best considered by the CPS when deciding whether or not to charge at all.

The conduct covered includes not just direct physical contact with the victim but also covers contacting a victim for sexual gratification (for example, by telephone or social media) and making a victim perform sexual acts even if the defendant is not directly involved, or even physically present (for example where the victim is required to perform sexual acts over the internet). We include these two latter categories to cover conduct we found in the cases we examined ${ }^{55}$ and conduct seen in recent sexual offence cases ${ }^{56}$.

\footnotetext{
${ }^{53}$ For example, EJ Griew Dishonesty - The objections to Feely and Ghosh [1985] Crim LR 341 and Law Commission Legislating the Criminal Code: Fraud and Deception (1999, London: The Stationery Office) (Law Com 155) paras 5.1-5.53

${ }^{54}$ See Adomako [1995] 1 AC 171.

${ }^{55} \mathrm{R} v$ Wilkie [2012] 2 Cr App R (S) 68 and R v Baljit Singh(2006) Leicester Crown Court, unreported (Rod Chaytor Phone sex cop accused The Mirror, 26 October 2006).

${ }^{56}$ See most recently $R v$ Bingham [2013] Cr App R 29.
} 
Finally, the suggested offence would sufficiently label the defendant's conduct. It would be clear what the defendant had done. S/ he could be sentenced appropriately for the sexual wrong at the heart of the offence.

\section{Conclusion}

MiPO should survive the Law Commission's current consultation, but as the parent of clearer, more focused offences which properly reflect the misconduct involved and reflect the truth of who in modern society holds positions of power. Proposals for reform that do not cover sexually exploitative abuse of power separately would be incomplete and we urge the Law Commission to include a sexual offence in their final report. 